\title{
Salmonella Intracellular Lifestyles and Their Impact on Host-to-Host Transmission
}

\author{
M. GRACIELA PUCCIARELLI1,2 and \\ FRANCISCO GARCÍA-DEL PORTILLO ${ }^{1}$
}

${ }^{1}$ Laboratory of Intracellular Bacterial Pathogens, Departamento de Biotecnología Microbiana, Centro Nacional de Biotecnología-Consejo Superior de Investigaciones Científicas (CNB-CSIC), Madrid, Spain; ${ }^{2}$ Centro de Biología Molecular Severo Ochoa (CBMSO-CSIC), Departamento de Biología Molecular, Universidad Autónoma de Madrid, Madrid, Spain

\begin{abstract}
More than a century ago, infections by Salmonella were already associated with foodborne enteric diseases with high morbidity in humans and cattle. Intestinal inflammation and diarrhea are hallmarks of infections caused by nontyphoidal Salmonella serovars, and these pathologies facilitate pathogen transmission to the environment. In those early times, physicians and microbiologists also realized that typhoid and paratyphoid fever caused by some Salmonella serovars could be transmitted by "carriers," individuals outwardly healthy or at most suffering from some minor chronic complaint. In his pioneering study of the nontyphoidal serovar Typhimurium in 1967,

Takeuchi published the first images of intracellular bacteria enclosed by membrane-bound vacuoles in the initial stages of the intestinal epithelium penetration. These compartments, called Salmonella-containing vacuoles, are highly dynamic phagosomes with differing biogenesis depending on the host cell type. Single-cell studies involving real-time imaging and gene expression profiling, together with new approaches based on genetic reporters sensitive to growth rate, have uncovered unprecedented heterogeneous responses in intracellular bacteria. Subpopulations of intracellular bacteria displaying fast, reduced, or no growth, as well as cytosolic and intravacuolar bacteria, have been reported in both in vitro and in vivo infection models. Recent investigations, most of them focused on the serovar Typhimurium, point to the selection of persisting bacteria inside macrophages or following an autophagy attack in fibroblasts. Here, we discuss these heterogeneous intracellular lifestyles and speculate on how these disparate behaviors may impact host-to-host transmissibility of Salmonella serovars.
\end{abstract}

\section{INTRODUCTION}

The bacterial species Salmonella enterica comprises Gram-negative pathogenic microorganisms that cause infections in humans and livestock. S. enterica is subdivided into six subspecies, with subspecies I responsible for infections in warm-blooded vertebrates, including mammals and birds $(\underline{1}, \underline{2})$. To date, $>2,500$ serovars have been reported in subspecies I. Some of these serovars are host adapted, whereas others infect a broad range of hosts. Host-adapted serovars cause systemic infections that result in typhoid (paratyphoid) fever and bacteremia. Among these serovars are Typhi, Paratyphi A, Paratyphi C (humans), Cholerasuis (swine), Dublin (cow), and Gallinarum (fowl). Nontyphoidal serovars normally cause self-limiting gastroenteritis, although the severity of the infection varies depending on the immune

Received: 14 February 2017, Accepted: 3 March 2017, Published: 21 July 2017

Editors: Fernando Baquero, Hospital Ramón y Cajal (IRYCIS), Madrid, Spain; Emilio Bouza, Hospital Ramón y Cajal (IRYCIS), Madrid, Spain; J.A. Gutiérrez-Fuentes, Complutensis University, Madrid, Spain, and Teresa M. Coque, Hospital Ramón y Cajal (IRYCIS), Madrid, Spain Citation: Pucciarelli MG, García-Del Portillo F. 2017. Salmonella intracellular lifestyles and their impact on host-to-host transmission. Microbiol Spectrum 5(4):MTBP-0009-2016. doi:10.1128 Imicrobiolspec.MTBP-0009-2016.

Correspondence: F. Garcia-del Portillo, fgportilloacnb.csic.es (c) 2017 American Society for Microbiology. All rights reserved. 
defense status of the host and/or a unique genetic makeup that may render the clone highly invasive. An example is the recently characterized invasive serovar Typhimurium isolates that cause systemic disease in HIV-infected individuals of sub-Saharan African countries ( $\underline{3}, \underline{4})$ and Latin America ( $\underline{5})$. Importantly, high transmissibility has been reported for all serovars, especially in those areas in which hygiene conditions in water and food are poor. The ability of all $S$. enterica serovars to cause persistent asymptomatic infections, especially following infection by host-adapted serovars, imposes more difficulties on control of transmission $(\underline{6}, \underline{7})$. This capacity to persist in the host without causing pathology has attracted physicians and microbiologists for more than a century, given its undoubtable negative impact on pathogen eradication. The reader is directed to the pioneering book The Carrier Problem in Infectious Diseases by Ledingham and Arkwright, which in 1912 exhaustively compiled all existing information about cases of asymptomatic carriers and their impact on pathogen transmission ( $\underline{8})$. These authors focused on six diseases known at that time to have high transmission rates, including typhoid and paratyphoid fever, diphtheria, epidemic cerebrospinal meningitis, dysentery, and cholera ( $\underline{8})$. Studies performed in mouse asymptomatic chronic infection models using the serovar Typhimurium have identified pathogen genes required to persist in the animal for long periods of time (weeks to a few months) $(\underline{9}, \underline{10})$. These studies also showed that serovar Typhimurium evolves during a chronic infection in the host and that this condition selects for adaptive mutations (9). This is an intense and fascinating area of research that will certainly aid to combat Salmonella transmissibility among individuals. We also refer to the chapter in this book by WolfDietrich Hardt and colleagues, which addresses withinhost evolution in Salmonella and the transmission of the virulent genotype in populations differentially affected by antibiotic treatments.

S. enterica is one of the bacterial pathogens in which the ability to invade eukaryotic cells was first reported. Using a guinea pig model in which the animals were challenged with serovar Typhimurium, Takeuchi demonstrated that bacteria transiently disrupted the brush border during the penetration of enterocytes, to later be confined within membrane-bound vacuoles (11). These pioneering observations were later confirmed in vitro using cultured cell lines such as human epithelial HeLa cells $(12,13)$. Subsequent cell biology studies focused on defining the intracellular trafficking route of the phagosomal compartment harboring serovar Typhimurium, coined the Salmonella-containing vacuole (SCV) in the initial studies (14). Current data support a variety of SCV "prototypes" with disparate biogenesis routes depending on the infected host cell type (15). This disparity may reflect differences between host cell defenses responding to the intruder microbe and the survival strategies used by the pathogen. In most cases, these different SCV types and pathogen-host interactions are observed even in the same tissue or organ (Fig. 1). The bacterial strains and host cells used, ranging from established phagocytic and nonphagocytic cell lines of tumor or nontumor origin to primary cultures and organoids (16-18), are also variables that affect SCV biogenesis. For example, entry of serovar Typhimurium into macrophages selects for a subpopulation of persistent intracellular bacteria (19). This observation denotes that the transition to the intracellular niche of phagocytic cells can promote persistence and, as a result, transmissibility.

Much recent data also sustain the capacity of serovar Typhimurium to break the SCV membrane and reach the cytosol of epithelial cells $(20,21)$, a favorable microenvironment thought to favor massive pathogen proliferation. On the other hand, there is accumulating evidence about distinct strategies used by this pathogen to limit proliferation and persist inside the infected host cell. In this chapter, we evaluate what is known about the intraphagosomal and cytosolic lifestyles of Salmonella and their potential relationships with two phenomena known to enhance host-to-host transmissibility: (i) localized intestinal inflammation with massive loss of bacteria in the stool and (ii) the establishment of chronic persistent infections. Both conditions predispose to abrupt or periodic shedding of bacteria to the external (outside the host) environment.

\section{SALMONELLA TRANSITION TO THE INTRACELLULAR NICHE IN THE EUKARYOTIC CELL}

Typhoidal and nontyphoidal S. enterica serovars invade eukaryotic cells using effector proteins translocated by specialized type III secretion apparatuses encoded in the Salmonella pathogenicity islands 1 (SPI-1) and 2 (SPI-2) $(\underline{2}, \underline{22}, \underline{23})$. Hereinafter, we refer to these systems as T1 and T2, respectively. Invasion of nonphagocytic cells has been extensively studied in immortal cultured epithelial cell lines such as HeLa, derived from human cervical cancer cells. Entry into the epithelial cell is of paramount importance for Salmonella pathogenesis since it allows the pathogen to penetrate the intestinal barrier. At the 


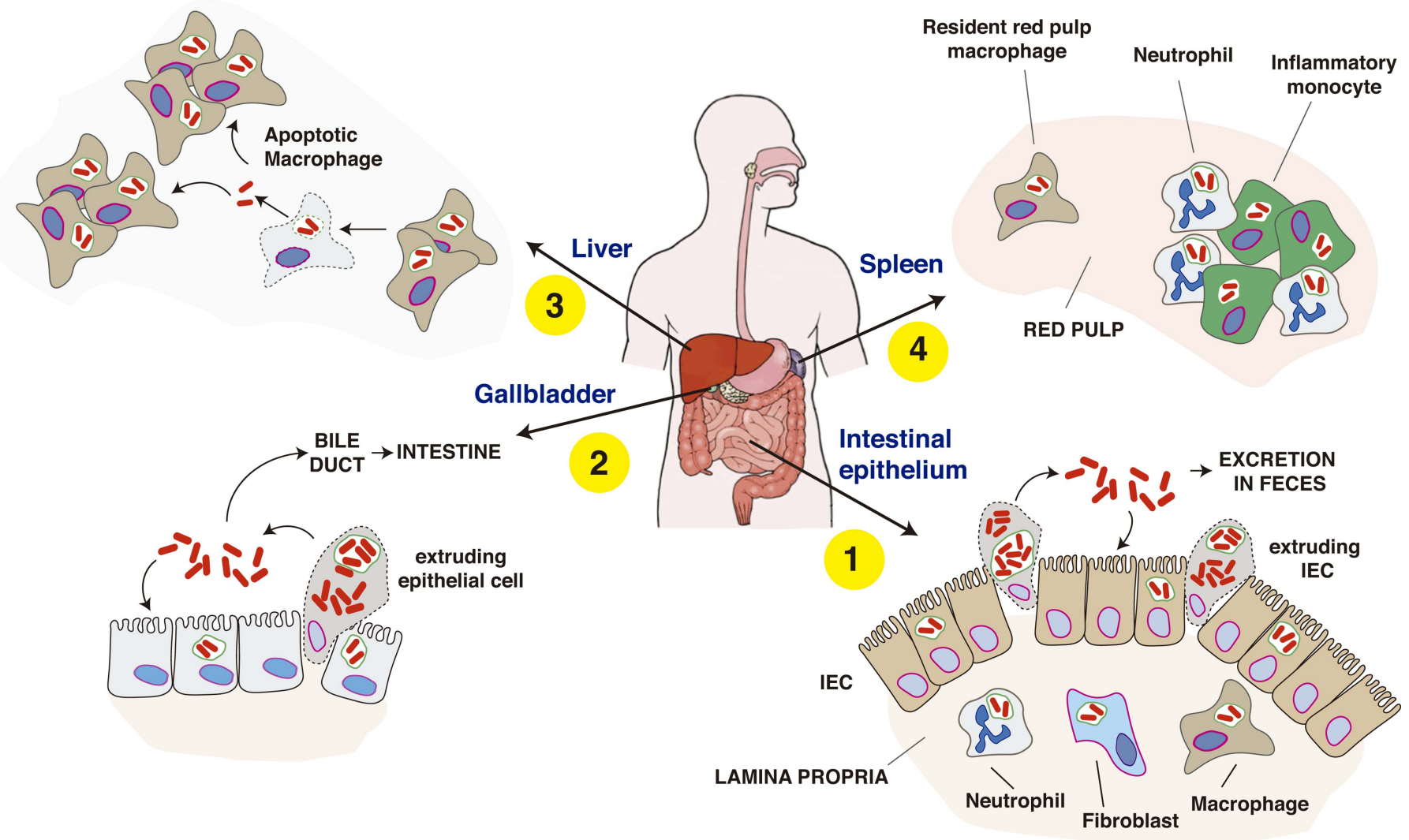

FIGURE 1 Distinct intracellular lifestyles of S. enterica serovar Typhimurium reported in various host locations during local inflammation of the intestine or acute systemic disease. (1) Limited proliferation of serovar Typhimurium in intestinal epithelial cells (IECS) during penetration of the intestinal barrier. The pathogen proliferates actively in a few IECS, which are rapidly extruded by a mechanism that depends on the inflammasome proteins NAIP/NLRC4. This proliferation was reported to occur within phagosomes and in the cytosol. Bacteria have also been observed in phagocytic (neutrophils, macrophages) and nonphagocytic cells (fibroblasts) in the underlying lamina propria. (2) Extrusion of heavily infected epithelial cells observed in the epithelium lining the gallbladder. As in the IECs, there is also evidence for replication of intracellular cytosolic serovar Typhimurium cells. (3) Serovar Typhimurium targets mainly macrophages in the liver. The most-accepted models support an increase in infection foci due to subsequent episodes of macrophage infection, a few rounds of intracellular replication of the pathogen, and reinfection of nearby macrophages. The intracellular lifestyle in these macrophages is entirely intraphagosomal. (4) Serovar Typhimurium colonizes distinct types of phagocytes in the red pulp of the spleen. The infection is highly contained by inflammatory monocytes and neutrophils, although some bacteria colonize and persist in resident macrophages. Note that the proliferation detected in the few epithelial cells that extrude in the intestinal epithelium and gallbladder ultimately favors shedding of the pathogen outside the host. Although not shown, serovar Typhimurium has also been shown to persist in macrophages present in mesenteric lymph nodes.

mechanistic level, translocated T1 effectors alter cytoskeleton dynamics to recruit actin to the site of bacterial contact and to obtain in this manner the required mechanical force for bacterial ingestion. This mode of entry, known as "trigger," is accompanied by massive reorganization of the actin cytoskeleton and the forma- tion of membrane ruffles that capture the invading bacterium to culminate in its efficient ingestion (24). T1 effectors involved in this process include SopB, SopE, and SopE2, which contribute to bacterial invasion and biogenesis of the early SCV compartment $(\underline{2}, \underline{25})$. SopB function has been linked to (i) actin rearrangement 
promoted by the small GTPase Rho; (ii) annexin A2 recruitment, which facilitates actin accumulation; and (iii) the generation of phosphatidylinositol 3-phosphate by recruiting the small GTPase Rab5 and the phosphatidylinositol 3-kinase Vps34 (2). The T1 effectors SopE and SopE2 act as guanine nucleotide exchange factors of the small GTPases Rac1 and Cdc42. Activation of these two GTPases leads to actin reorganization promoted by stimulation of actin nucleation factors of the Wiskott-Aldrich syndrome protein (WASP) family
(26). SipA and SipC, which promote actin bundling, are additional T1 effectors required for invasion. Following bacterial internalization, SptP, another T1 effector, reverses the alterations to the cell cytoskeleton by inactivating the Rho GTPase $(\underline{2}, \underline{25}, \underline{27})$.

The nontyphoidal serovars Typhimurium and Enteritidis can also invade nonphagocytic cells by T1independent mechanisms that mimic the zipper-like mode of entry (Table 1) (28- 11 ). This entry process is driven essentially by adhesin-receptor interactions. The

TABLE 1 Salmonella and host responses discussed in this chapter with probable impact on host-to-host transmission of the pathogen

\begin{tabular}{|c|c|c|c|}
\hline Host and/or pathogen response & $\begin{array}{l}\text { Pathogen functions } \\
\text { or effectors involved }\end{array}$ & $\begin{array}{l}\text { S. enterica serovar(s) in which } \\
\text { it has been investigated }\end{array}$ & Reference(s) \\
\hline Selection of persister bacteria inside macrophages & toxin-antitoxin (TA) loci & Typhimurium & $\underline{19}$ \\
\hline $\begin{array}{l}\text { Selection of small-colony variants in persistent } \\
\text { infections of fibroblasts }\end{array}$ & $\begin{array}{l}\text { hemL, Ipd, and aro } D \\
\text { (inactivating mutations) }\end{array}$ & Typhimurium & $\underline{75}$ \\
\hline $\begin{array}{l}\text { Production of toxins by the pathogen to restrain } \\
\text { growth }\end{array}$ & $\begin{array}{l}\text { TA loci (suspected in host) } \\
\text { and TacT toxin }\end{array}$ & Typhimurium & $\underline{19}, \underline{135}$ \\
\hline Pathogen proliferation in cytosol of epithelial cells & SPI-1 (T1), YdgT, CorA, and RecA & Typhimurium & $\underline{20}, \underline{21}, \underline{141}$ \\
\hline SPI-1-mediated invasiveness & $\begin{array}{l}\text { SPI-1 (T1) and dedicated effectors } \\
\text { (SopB, SopE, SopE2, SipA, SipB, } \\
\text { and SptP) }\end{array}$ & $\begin{array}{l}\text { Typhimurium, Typhi, Enteritidis, } \\
\text { and many other serovars }\end{array}$ & $\underline{142}$ \\
\hline $\begin{array}{l}\text { SPI-1-independent invasion and pathogenicity } \\
\text { in animal models }\end{array}$ & RcsK and PagN; other? & $\begin{array}{l}\text { Typhimurium, Enteritidis, } \\
\text { and Gallinarum }\end{array}$ & $\underline{29}, \underline{34}, \underline{143}$ \\
\hline $\begin{array}{l}\text { Selective autophagy of a subpopulation of } \\
\text { intracellular bacteria triggered by a membranous } \\
\text { aggresome }\end{array}$ & SPI-2 & Typhimurium & $\underline{57}$ \\
\hline Inflammasome activation in intestinal epithelial cells & $\begin{array}{l}\text { NAIP/NLRC } 4 \text { and caspase-1 } \\
\text { (host proteins) }\end{array}$ & Typhimurium & $\underline{63}$ \\
\hline $\begin{array}{l}\text { Uptake of distinct carbon sources (polysaccharides?) } \\
\text { by intracellular bacteria in chronically infected hosts }\end{array}$ & $\begin{array}{l}\text { KdgR (proposed enhanced } \\
\text { activity of this regulator) }\end{array}$ & Typhimurium & $\underline{77}$ \\
\hline $\begin{array}{l}\text { Uptake of nutrients (e.g., amino acids) via the Sif } \\
\text { tubular membranous extensions }\end{array}$ & $\begin{array}{l}\text { SPI-2 effectors involved in Sif } \\
\text { formation; dedicated pathogen } \\
\text { transporters? }\end{array}$ & Typhimurium & $\underline{78}$ \\
\hline Active proliferation in the host (acute infection) & SPI-2; ubiquinone synthesis & Typhimurium & $\underline{82}$ \\
\hline $\begin{array}{l}\text { Modulation of the inflammatory status of the } \\
\text { pathogen (M1/M2) by intracellular bacteria }\end{array}$ & $\begin{array}{l}\text { Unknown (response associated } \\
\text { to bacterial load) }\end{array}$ & Typhimurium & $\underline{115}$ \\
\hline $\begin{array}{l}\text { High proliferation in a low percentage of infected } \\
\text { cells in gallbladder and intestinal epithelia }\end{array}$ & Unknown & Typhimurium & $\underline{60}, \underline{63}$ \\
\hline
\end{tabular}

aSPI-1, Salmonella-pathogenicity island. 
pathogen surface proteins Rck and PagN have been implicated in this process $(29, \underline{30})$. T1-independent entry mediated by the pathogen occurs in fibroblast and epithelial cell lines $(28,31)$. Of note, the nontyphoidal serovar Typhimurium can cause infections in chicken, bovine, and murine animal models independently of a functional T1 system (29). Similar observations were reported for the serovar Enteritidis $(32,33)$ and the host-adapted serovar Gallinarum (Table 1) (34). Thus, Salmonella could exploit multiple entry mechanisms of nonphagocytic cells (29), with preferable usage in specific hosts and with probable benefit for host-to-host transmission.

Internalization of Salmonella serovars into professional phagocytic cells such as macrophages or dendritic cells has also been studied in detail. Alternative modes of entry can occur depending on whether the entry is triggered by the pathogen (e.g., via T1-translocated effectors) or driven by the phagocyte using dedicated receptors that promote phagocytosis. Early reports using serovar Typhimurium suggested that the phagosomal compartments harboring wild-type and isogenic T1defective strains were indistinguishable (35). However, later studies in macrophages showed marked differences. Thus, the phagosomal compartment formed after T1induced entry or the uptake of complement-opsonized serovar Typhimurium was permissive for growth, whereas IgG-opsonized or nonopsonized bacteria were killed in the phagosome (36). The fate of serovar Typhimurium inside macrophages, the preferred cell type targeted by this pathogen in vivo (Fig. 1), can be therefore highly variable depending on the mode of entry (37).

\section{BIOGENESIS AND MATURATION OF THE SCV}

Early studies in the 1980s showed that serovar Typhimurium survival inside macrophages was a requisite for causing disease in mice (38). This observation paved the way to analyze this phagosomal compartment in more detail. As mentioned above, this compartment is now generically known as the Salmonella-containing vacuole in both phagocytic and nonphagocytic cells (20, 39-42). A hallmark of the SCV is its pronounced dynamics in spatial and temporal terms involving interactions with various organelles of the infected cell, including early and late endosomes and the Golgi apparatus $(\underline{43}, 44)$. Intracellular trafficking of the SCV has been intensively examined in vitro in cultured cell lines. These studies demonstrated the intervention of protein effectors translocated by the T1 and T2 systems. T1 effectors partici- pate in the early stages of SCV maturation, while T2 effectors act a few hours later (2- to 3 -h postinfection) to model the intracellular replicative or survival niche. The literature on Salmonella T1 and T2 effectors linked to SCV biogenesis is abundant. We refer to excellent reviews that summarize the action of translocated pathogen effector proteins that engage fundamental processes in the infected cell, including cytoskeleton dynamics, vesicular trafficking, and cytokinesis $(\underline{2}, \underline{22}, \underline{23}, \underline{43}, \underline{45}-$ 47). Some of the activities demonstrated for T1 and T2 effectors include chemical modification of eukaryotic targets with activities such as acetyltransferase, ADPribosyltransferase, tyrosine phosphatase, E3 ubiquitin ligase, deubiquitinase phosphothreonine-ligase, cysteine protease, or glycerophospholipid cholesterol acyltransferase $(\underline{2}, \underline{22}, \underline{46})$. Other Salmonella effectors act as enzymes altering certain metabolite pools in the host cell (e.g., phosphoinositide phosphate) or mimicking host proteins that regulate nucleotide exchange in GTPases of the Rho and Rab families $(\underline{26}, \underline{48}-\underline{50})$.

The presence or absence of defined sets of effectors can contribute to host specificity. In human macrophages, the SCV containing serovar Typhi is decorated with the GTPase Rab29, which correlates to a state of survival and low proliferation rate for intracellular bacteria (51). However, ectopic expression in serovar Typhi of the T1/T2 effector GtgE, absent in this serovar, results in Rab29 proteolysis and augmented growth in human macrophages (Fig. 2A) (51). This observation links the intracellular survival and persistence of serovar Typhi to a defined repertoire of type III effectors. Based on these findings, it is tempting to speculate that the absence or presence of certain T1 or T2 effectors could direct the maturation of the SCV to either a persistencepromoting environment or a permissive niche for rapid growth. GtgE, encoded by genomes of nontyphoidal serovars, also targets the GTPase Rab32, and this process facilitates proliferation of nontyphoidal serovars such as Typhimurium. Mouse macrophages, which normally restrict serovar Typhi intracellular growth, become permissive for recombinant serovar Typhi strains expressing GtgE, similarly to how they behave when infected with broad-range nontyphoidal serovars such as Typhimurium (Fig. 2A) (50).

The characterization of the SCV trafficking route led to the identification of membrane extensions emanating from the phagosomal compartment, known as Salmonella-induced filaments (Sifs) (52). This tubular network is enriched in lysosomal membrane glycoproteins and its mechanism of formation has been deciphered in detail $(47,53)$. Sif formation is driven by the 

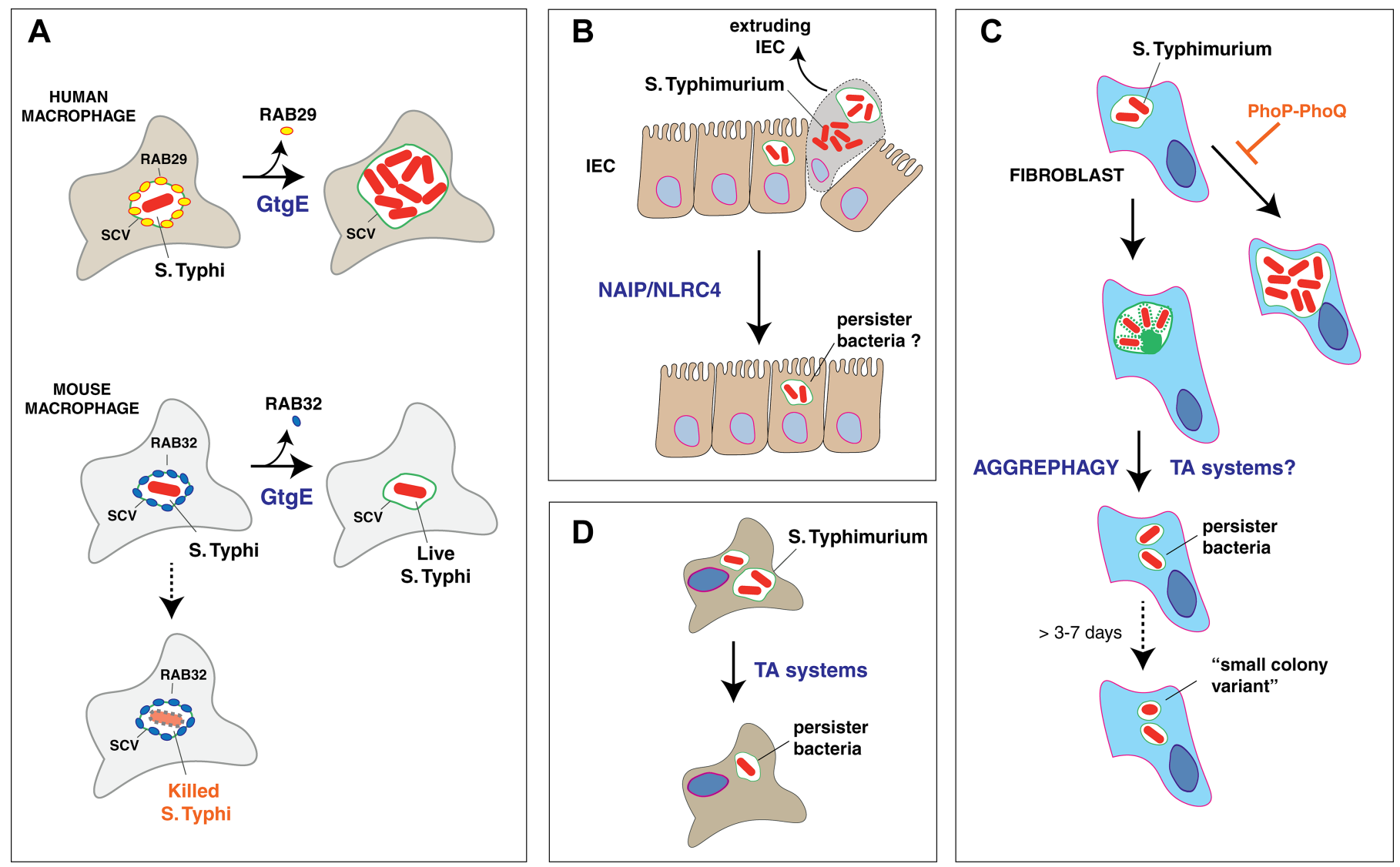

FIGURE 2 Representative conditions reported to control intracellular growth of serovars Typhimurium and Typhi favoring persistence inside the infected cell. These examples include (A) the production by intracellular serovar Typhi of defined type III effector proteins targeting Rab proteins (see text for details); (B) inflammasome intervention in IECs to exclude cells heavily infected with serovar Typhimurium; and (C) attenuation of intracellular growth in fibroblasts linked to changes in yet undefined functions of intracellular serovar Typhimurium regulated by the two-component regulatory system PhoP-PhoQ or other regulators (SlyA, RpoS). This process could be either followed by or occur concomitantly with selective autophagy attack (aggrephagy). Formation of small-colony serovar Typhimurium variants has also been shown to occur in fibroblasts at long postinfection times. (D) The actions of toxins encoded in TA loci contribute to the selection of serovar Typhimurium persisters following ingestion by macrophages.

T2 effector SifA, which links the adaptor protein SKIP and kinesin to the SCV and the microtubule network to induce endosome tubulation (53). Other T2 effectors such as SseJ, which modifies lipid content of the SCV by increasing the amount of cholesterol esters, are required for Sif formation (2). Sifs are a type of structure not observed in uninfected cells, as was reported further for other tubular networks associated with serovar Typhimurium infection $(47,53)$. The ultimate benefit of this elaborated membranous network is at present unknown, although recent studies favor a role in nutrient acquisition by the pathogen (47). The lack of T2 effectors involved in the generation of these tubular structures results in attenuation of serovar Typhimurium in the mouse model $(\underline{54}, 55)$, which supports a relevant role for this structure in Salmonella pathogenesis. A host protein that contributes to the biogenesis of the SCV and to the connection of this compartment with Sifs is the lysosomal adaptor named Pleckstrin homology domaincontaining protein family member 1 (PLEKHM1) (56). This protein interacts with the T2 effector SifA, the host GTPase Rab7, and the HOPS complex, a multisubunit homotypic fusion and vacuole protein sorting platform. Lack of PLEKHM1 leads to the formation of abnormal vacuoles containing serovar Typhimurium, to the absence of Sifs, and to a lower intracellular bacterial load 
in epithelial cells and fibroblasts (56). A slightly decreased bacterial load in mice lacking PLEKHM1 was also claimed in vivo (56). These data are relevant since they unequivocally link to the capacity of serovar Typhimurium to modify the SCV compartment, as observed in in vitro cultured cell lines, to proliferation in the animal organs. Future studies should address whether the observed changes in bacterial load observed in vivo are manifested at the single-cell level.

A recent report describes another example of host membrane manipulation by serovar Typhimurium with direct consequences for the progeny of intracellular bacteria. During infection of fibroblasts, serovar Typhimurium induces the formation of Sif-like structures that do not evolve into an intricate network. Instead, these Sif-like tubular endosomes collapse into a membranous aggregate (aggresome) that recruits autophagy machinery (57). The autophagosome formed in response to the aggregate digests this extraneous body as well as those nearby bacteria captured in the autophagosomal compartment (57). Intracellular bacteria located far from the aggresome are not attacked by the autophagy machinery and remain alive. This strategy allows bacteria to "self-control" their progeny within the infected cell. These persistently infected cells could favor host-tohost transmissibility by periodic release of intracellular bacteria.

\section{INTRAPHAGOSOMAL VERSUS CYTOSOLIC INTRACELLULAR LIFESTYLE}

A large body of evidence has shown that serovar Typhimurium can actively lyse the membrane of the nascent SCV, resulting in colonization of the host cell cytosol $(20)$. This phenotype has been observed mainly in epithelial cells, both in vitro in distinct epithelial cell lines (58) and in vivo (59) (Fig. 1). Of much interest, cytosolic bacteria "hyperreplicate" (58), leading to destruction of the infected epithelial cell. Unlike intraphagosomal bacteria, cytosolic bacteria express flagella and have a functional T1 secretion system (59). In the gallbladder epithelium, the hyperreplication of cytosolic bacteria results in the extrusion of infected cells harboring a large progeny of intracellular bacteria $(\underline{59}, 60)$ (Fig. 1). The phenomenon is also observed in polarized intestinal epithelial cells (59). This pathogen-induced "exfoliation" resembles that taking place during natural turnover of the intestinal epithelium. However, a major difference is that the epithelial cell infected with serovar Typhimurium undergoes inflammatory cell lysis (pyroptosis), induced by activation of caspase-1 (59), which leads to the release of proinflammatory cytokines such as interleukin-18 (IL-18). These data highlight a new concept in pathogen biology: as was previously shown for macrophages and other phagocytic and immune cells such as dendritic cells and neutrophils, epithelial cells harbor inflammasomes that respond to Salmonella infection $(61, \underline{62})$. Inflammasomes are cytoplasmic signaling complexes that recognize pathogen components such as lipopolysaccharide (LPS), flagellin or proteins of the T1 secretion apparatus and induce the inflammatory caspase- 1 and caspase-11 $(61,62)$. Caspase activation is the key step required for production of inflammatory cytokines (IL- $1 \alpha$, IL-1 $\beta$, and IL-18), which is followed by their release concomitant to the cell death $(61,62)$. Are inflammasomes an important host factor affecting or promoting Salmonella transmissibility? A recent study focused on the role of inflammasomes in restricting Salmonella proliferation in intestinal epithelial cells. Two main components of the inflammasome platform that is active in epithelial cells, NAIP/NLRC4 (neuronal apoptosis inhibitor protein/NOD-like receptor subfamily $\mathrm{C} 4$ ) and caspase-1, contribute to extrusion of heavily infected epithelial cells (Fig. 2B) (59, 63). This phenomenon, however, does not guarantee bacterial clearance. In wild-type mice, serovar Typhimurium persists for $36 \mathrm{~h}-$ the last time point measured in the study-in intestinal epithelial cells harboring a low average number ( 2 to 3 cells) of intracellular bacteria (63). These data suggest that inflammasomes may become active at early infection times to control the burst of intracellular replication occurring in a few epithelial cells of the intestinal barrier. This situation presents a striking parallelism with the control of an early replication burst taking place in fibroblasts, which is aborted following aggrephagy of an endosomal membranous aggregate (Fig. 2C) (57).

Based on these observations, we could speculate on an exploitation of the inflammasome machinery by serovar Typhimurium to "self-control" and to attenuate intracellular growth. This condition could certainly preserve integrity of the infected cell and ensure transmissibility. On the pathogen side, extrusion of heavily infected cells together with persistence in some other cells of the epithelial barrier (both in intestine and gallbladder) seems doubly beneficial. Thus, such strategy results in release of many bacteria to the intestinal or gallbladder lumen, increasing the probability of reinfection and spreading to the external environment (Fig. 1). Whether there is a potential pathogen reservoir remaining after the control of the initial growth burst by the NAIP/NLRC4 
inflammasome axis (63) has not yet been investigated. Comparable long-term studies at the cellular level in the gallbladder are also lacking.

Strong evidence supporting the role of inflammasomes in control of serovar Typhimurium proliferation comes from the exacerbated bacterial growth in intestinal epithelial cells and increased colonization of lymph nodes noted in mice lacking components of this host defense (63). This has serious consequences for the host since the pathogen can then rapidly spread to deeper tissues. Still intriguing is the interplay between extrusion of heavily infected cells and the simultaneous presence of epithelial cells having low numbers of intracellular bacteria, which could act as reservoir. Noteworthy, there is also evidence of serovar Typhimurium targeting nonphagocytic stromal cells located in the intestinal lamina propria, in which the pathogen actively restrains growth (64). This response is driven by, among others, the master virulence two-component regulatory system PhoP-PhoQ (Fig. 2C) (65). The persistent infection of stromal cells by serovar Typhimurium indicates that other potential niches for intracellular persistence may exist at the level of the intestine, which could be explored in future studies.

The interaction of cytosolic bacteria with inflammasome components remains to be further clarified. Epithelial cells utilize caspase-11, responsible for inducing IL-18 expression, to respond to LPS located in the cytosol, but the exact source of this envelope component in vivo remains unknown. For serovar Typhimurium infection of epithelial cells, it was shown that intraphagosomal bacteria release LPS embedded in vesicles $(\underline{66})$. Whether caspase-11 recognizes the LPS produced by intraphagosomal bacteria and/or LPS released by actively growing cytosolic bacteria has yet to be determined.

\section{THE SCV AS A SUITABLE NICHE TO PROLONG HOST INFECTION IN A NONGROWING STATE}

Most studies focused on host-to-host transmissibility of Salmonella have exploited in vivo chronic infection models, especially those involving serovar Typhimurium and $129 \mathrm{X} 1 / \mathrm{SvJ}_{\mathrm{J}}$ inbred mice $(\underline{6}, \underline{67})$. In this model, a subset of the chronically infected mice often behave as "supershedders" ( $\left.>10^{8} \mathrm{CFU} / \mathrm{g}\right)$, and this phenomenon correlates with high numbers of bacteria in the lumen of the colon (68). This behavior probably reflects a failure in the capacity of the endogenous intestinal microbiota to control pathogen proliferation. The $129 \mathrm{X} 1 / \mathrm{SvJ}$ inbred mouse model allowed detection of potential niches for long-term infections such as macrophages located in mesenteric lymph nodes (69) and anti-inflammatory M2-type macrophages (70). The model also been exploited to identify pathogen functions required for these chronic infections, including, among others, T1 and T2 effector proteins, fimbrial proteins, regulatory proteins involved in outer membrane homeostasis, and proteins encoded in pathogenicity islands (10). In addition to these studies, clinical and epidemiological data show the gallbladder as another niche in which typhoidal and nontyphoidal Salmonella serovars could persist in chronic and asymptomatic infections, therefore ensuring host-to-host transmissibility $(\underline{71}, \underline{72})$. As mentioned above, the gallbladder epithelium is permissive for intracellular replication of serovar Typhimurium, but this phenomenon has been reported in acute infection models $(59,60)$. A comparative analysis in the gallbladder of chronically infected mice has not been performed to date. Besides the potential intracellular reservoir in the epithelial cells lining the gallbladder, biofilms formed on gallstones may contribute to pathogen transmissibility during asymptomatic and chronic infections $(73,74)$. The capacity of serovar Typhimurium to form biofilms in this niche has been demonstrated to require functions that ensure survival in the presence of high doses of bile salts as well as type 1 fimbriae, these latter involved in attachment to and persistence in gallstone surfaces $(\underline{74})$.

Despite this valuable information on the modes and functions that distinct Salmonella serovars exploit to persist in the host, no study has formally linked a defined intracellular lifestyle with long-term infection of the host. Indeed, we are still far from understanding how this pathogen adapts to live within the SCV phagosome in a nongrowing state. Some studies, however, provide clues supporting a unique lifestyle linked to persistence. Viable serovar Typhimurium has been isolated from cultured fibroblasts-in which bacteria show limited intracellular proliferation-as long as 21 days after entering into these cells (75). Many of the isolates rescued after such persistent infection of the fibroblast harbored mutations in the hemL, $l p d$, and aroD genes. Two of these mutations, hemL and $l p d$, impact respiratory rates, leading to a less oxidative environment and, as a consequence, to a less toxic environment ( 75$)$. The same applies to aroD, which decreases bacterial growth rate. These mutations confer a "small-colony variant" phenotype, which resembles the type of variants isolated from chronic infections caused by other important pathogens such Staphylococcus aureus (76). These 
small-colony variants in serovar Typhimurium, as in $S$. aureus, maintain a stable phenotype outside the eukaryotic cells and do not revert to fast-growing bacteria. The mechanisms by which a long residence inside the fibroblast selects for these types of mutations should be addressed in future studies. It is also important to note that these serovar Typhimurium variants become resistant to some specific classes of antibiotics, such as aminoglycosides (75), and that these isolates persist at higher rates than wild-type bacteria inside the fibroblast. This latter observation indicates that the adaptation to nongrowing intracellular state inside the SCV may be an advantage to persistence within the infected cell.

In line with these observations, recent studies have shown that serovar Typhimurium evolves in vivo during a long-term chronic infection of mice (9). Individually tagged bacteria were used to challenge $129 \mathrm{X} 1 / \mathrm{SvJ}$ mice in the chronic infection model. Point mutations that increased fitness in animal organs were selected in some dominant clones along the chronic infection. One of these mutations mapped to $k d g R(9)$, a transcriptional regulator that modulates uptake of distinct carbon sources. Intriguingly, the $\mathrm{KdgR}$ regulon favors persistence of serovar Typhimurium in vegetable soft rots in association with defined phytopathogens such as Pectobacterium carotovorum (77). This role in persistence was linked to increased uptake of carbon sources derived from pectin degradation and utilization of the Entner-Doudoroff pathway, both regulated by $\mathrm{KdgR}$ (77). Mammalian cells do not produce pectin, so it is tempting to speculate that the action of $\mathrm{KdgR}$ in intracellular serovar Typhimurium is related to the hydrolysis and product utilization of some yet unknown polysaccharide. Since KdgR variants with point mutations confer selective advantage in the mouse chronic infection model, it would be interesting to discern whether such a phenotype correlates with alterations in the intracellular lifestyle of the pathogen in distinct host cell types. Future studies will be valuable to obtain proof of concept relating physiological status of serovar Typhimurium in the SCV (or the cytosol) to preference for a defined outcome of the infection, in terms of chronic/asymptomatic or acute infection.

The nutritional status of serovar Typhimurium within the SCV has been recently addressed in macrophages and epithelial cells using a large collection of auxotrophic mutants in essential amino acids (78). This approach identified amino acids that are provided by the infected cell versus those that must be synthetized by the pathogen and, therefore, showed which metabolic pathways are preferentially used by actively growing bacteria. As an example, alanine is provided by the infected macrophage to the SCV, while that is the case of asparagine in the SCV of epithelial cells (78). These data imply distinct metabolic status of intracellular serovar Typhimurium depending on the host cell type. Interestingly, growth of defined auxotrophic mutants is restored in epithelial cells by supplementation of the corresponding amino acid only if intracellular bacteria induce Sif formation. This means that these endomembrane tubular extensions could facilitate nutrition acquisition by the pathogen. Such an assumption also correlates with the above-mentioned phenotype in fibroblasts, in which bacteria persist inside the SCV in the absence of stable Sifs (57).

Proteomic studies and phenotypic assays in metabolic mutants have also shown that fatty acids and glycerol are major energy sources used by serovar Typhimurium in vivo during acute infection of mice (79). Of interest, this study speculates about a marked flexibility in the pathways that the pathogen uses to metabolize host nutrients, ensuring in this manner an efficient metabolic flux even if some of the nutrients become scarce under specific conditions. Additional data obtained in cultured macrophages and epithelial cells pointed to glucose as a preferred energy source for intracellular replication ( $\underline{80}$, 81). Mutants defective for glycolysis from glucose are also impaired for successful colonization of mice $(\underline{80})$. Thus, serovar Typhimurium does not use a single type of nutrient as an energy source. This metabolic flexibility represents a clear obstacle for the host to control the infection.

Chronic infection models following challenge of mice with serovar Typhimurium purA ssaGH mutants, unable to proliferate in organs, have shown metabolic differences for bacteria in acute versus persistent infections (82). Mutations in metabolic functions required for acute infection, like some mapped to the $u b i C$ gene, have no effect on the persistence established by the purA ssa $\mathrm{GH}$ mutant. The $u b i \mathrm{C}$ mutation prevents ubiquinone synthesis and, as result, proliferation of wild-type bacteria. However, it has no effect on the purA ssaGH persistent mutant. As an exception, a mutation in $f a b B$, which encodes $\beta$-ketoacyl-acyl carrier protein (ACP) synthase I, required for biosynthesis of unsaturated fatty acids and cyclopropane, decreases substantially the persistence of the purA ssaGH double mutant (2). Intriguingly, small-colony variants appeared at high rate in the purA ssaGH fabB mutants when isolated from chronically infected mice, a phenomenon resembling that discussed in fibroblasts. 


\section{THE BATTLE FOR INTRACELLULAR SURVIVAL: A BALANCE BETWEEN HOST DEFENSES AND THE COUNTERACTING STRATEGIES OF THE PATHOGEN}

Host-to-host transmission of typhoidal and nontyphoidal Salmonella serovars is influenced by the rate of access to the intestinal lumen and proliferation of the pathogen. This ensures rapid exit outside the host via the intestinal tract. In addition, the maintenance of the pathogen in intracellular niches could potentially favor a periodic colonization of the intestine, allowing transmission of the pathogen to the external environment. The second mechanism implies a delicate balance between host defenses and strategies of the pathogen to remain alive in intracellular locations. Of note, recent data obtained in serovar Typhimurium support its capacity to intentionally establish a persistence state. Below, we discuss evidence sustaining this view.

The innate immune system controls intracellular infections by limiting nutrients to the intruder, producing antimicrobial peptides, releasing oxygen- and nitrogenderived reactive species, or acidifying the compartment containing the pathogen ( $\underline{83})$. Another process equally important in this respect is autophagy $(\underline{84}, \underline{85})$. However, autophagy is subverted by certain pathogens to acquire nutrient and membrane material for their own benefit $(\underline{86}, \underline{87})$. Important intracellular bacterial pathogens such as Coxiella burnetii, Francisella tularensis, or Brucella spp. divert nutrients from the autophagosomal compartment or even fuse and proliferate inside this specialized organelle (그). For serovar Typhimurium, contrasting data have been reported. These studies have shown (i) autophagy actively killing cytosolic serovar Typhimurium or bacteria contained in damaged SCV membranes (88-90), (ii) exploitation of autophagy to promote proliferation (91), and (iii) eradication of part of the progeny facilitating the establishment of perdurable persistent infections (57).

Models involving transgenic mice deficient in these innate defense mechanisms illustrate their role in controlling intracellular growth of serovar Typhimurium. Some examples are mice deficient in (i) the Nramp1 transporter, which imposes nutritional stress on the pathogen by removing essential divalent cations from the phagosomal compartment $(92,93)$; (ii) the NAPDH oxidase, responsible for the oxidative burst in phagocytes by producing reactive oxygen species (94); (iii) the nitric oxide synthase, which generates reactive nitrogen species (95); (iv) key elements of the inflammasome such as NLRP3 (NOD-like receptor family pyrin domain containing 3) and NLRC4, or the pyroptosis-inducing caspase-1 (63, 96-99); (v) components of the autophagy machinery such as Atg5 (100-102); and (vi) proinflammatory cytokines (tumor necrosis factor $\alpha$ and gamma interferon). Increased susceptibility to serovar Typhimurium infection and augmented intracellular replication rates linked to the lack of these defenses have been demonstrated in macrophages or embryonic fibroblasts obtained from these knockout transgenic mice (63, 99, 100, 103, 104). Collectively, these data show the important balance existing between host defenses and survival strategies of the pathogen that may result in a defined intracellular lifestyle. Fortunately, the number of studies addressing these changes in susceptibility to Salmonella infection from the host side is continuously increasing. Genome-wide association studies represent a nonbiased method to identify pathways related to human diseases, and this information can be exploited to identify important host proteins that can control Salmonella growth. A recent study focused on an allele (T300A) in an autophagy protein, ATG16L1, previously identified as one of the 140 risk loci linked to Crohn's disease (105). Transcriptome analyses in cells obtained from wild-type and ATG16L1-T330A cells exposed to pathogen-derived compounds identified a set of genes differentially expressed. One of them, CLEC12A, was associated with autophagy proteins. In vitro and in vivo infection models revealed that CLEC12A modulates autophagy of serovar Typhimurium and that mice lacking this protein are more susceptible to the infection (105). Thus, from genome-wide association analyses it is possible to unravel new host functions that control the intracellular lifestyle of serovar Typhimurium (106) and, as a consequence, have impact on host-tohost transmission.

Studies based on RNA interference targeting the human kinome have also led to the identification of host factors involved in restricting serovar Typhimurium intracellular proliferation, including kinases interacting with Akt1/protein kinase B (107). Another kinase, TANK-binding kinase 1 (TBK1), recruits autophagy proteins to ubiquitinated cytosolic serovar Typhimurium $(108,109)$. TBK1 has been shown to maintain the integrity of the SCV membrane, preventing access to the cytosol (110). Therefore, TBK1 seems to play a dual role, as a defense mechanism favoring serovar Typhimurium intravacuolar persistence or, alternatively, stimulating autophagy of cytosolic bacteria that escape from the SCV.

DalS, a transporter used by intracellular serovar Typhimurium to capture D-alanine and required for virulence (111), also exemplifies the interplay existing 
between host defense mechanisms and pathogen strategies to survive and persist in the intracellular environment. D-Alanine is a substrate of the eukaryotic enzyme D-amino acid oxidase (DAO), which generates reactive oxygen molecules from this D-amino acid. The DalSmediated import of D-alanine by intracellular serovar Typhimurium contributes to its survival within neutrophils during the early stage of the infection by decreasing availability of this substrate to DAO. This strategy has been proposed as a step crucial for the pathogen to withstand host defenses, allowing the infection of morepermissive host cells (112).

Novel transcriptomic sequencing technologies involving dual RNA-seq have generated much information about regulatory RNAs and genes that are upand downregulated in both serovar Typhimurium and the host cell (113). These data, obtained in the growthpermissive intracellular environment of HeLa epithelial cells, provide a valuable insight into host and pathogen functions modulating bacterial load, activity of signaling pathways, and production of proinflammatory cytokines at various times postinfection (113). These robust technologies could also be applied to examine the pathogen-host interplay in conditions that impede massive pathogen intracellular growth (i.e., activated macrophages or fibroblasts). The possibility of analyzing gene expression at the single-cell level (114) should certainly provide new clues on how bacteria interact with a defined host cell type and how such cross talk evolves over time. A recent single-cell RNA-seq study proves this postulate, demonstrating that the physiological status of macrophages bearing either high or low amounts of serovar Typhimurium cells differs substantially (115). Macrophages harboring persistent nongrowing bacteria display an M1 proinflammatory status, whereas those with a large number of fast-growing bacteria show an M2 anti-inflammatory state $(\underline{115})$.

\section{HETEROGENEITY OF SALMONELLA INFECTIONS AND ITS PROBABLE IMPACT ON HOST-TO-HOST TRANSMISSIBILITY}

In vivo studies reveal a plethora of encounters taking place between invading bacteria and distinct host cell types in distinct anatomical sites $(116,117)$. Early studies showed a preference of serovar Typhimurium to target macrophages in target organs such as liver and spleen $(118,119)$. Other host cell types such as neutrophils, dendritic cells, and nonphagocytic stromal cells are also infected. Mathematical modeling and real-time video microscopy indicate that host cells repeatedly encounter bacteria and that these contacts translate to infection in a relatively low number of the cases. About $5 \%$ of the macrophages contacted are ultimately infected (117). Moreover, the number of intracellular serovar Typhimurium bacteria per infected macrophage remains low (3 to 4 bacteria/cell). This latter observation involves a scenario based on relatively low rounds of pathogen replication followed by lysis of the infected cells and reinfection of neighboring cells. This strategy has been proposed to be responsible for the increase in infection foci and pathogen dissemination through the organ $(120)$. These in vivo data occasionally remain underappreciated when using in vitro infection models, in which often high intracellular proliferation rates are detected, especially in established cell lines of tumor origin (58). Nonetheless, high intracellular replication rates have been observed for serovar Typhimurium in vivo in defined sites, as epithelial cells of the gallbladder (59, 60) and intestinal epithelia (63) (Fig. 1). Interestingly, only a relatively small fraction of infected epithelial cells supports exacerbated intracellular proliferation of bacteria (see Fig. 1 of reference 63). This evidence supports a tight control of serovar Typhimurium intracellular replication that might be effective when host defenses and pathogen counterattack intersect.

Powerful microscopy technologies, including realtime imaging of live cells in culture and in the whole animal together with fluorescent growth rate-based reporters, have shown that these encounter episodes of different nature occur concomitantly in a reduced surface area of the infected tissue. Heterogeneous subsets of slow- and fast-growing serovar Typhimurium in intracellular locations are observed in these studies (121). Bacteria either displaying slow growth or that are nondividing were shown to survive better following an antimicrobial challenge (121). Disparate rates of pathogen death were also found in populations of infected macrophages, polymorphonuclear cells, or inflammatory monocytes that occupy the spleen red pulp in the first days postinfection (122). Of interest, reactive oxygen species produced by neutrophils and inflammatory macrophages reduce bacterial burden, although they are unable to eradicate the pathogen. This partial control of the primary infection facilitates transmission of bacteria to more permissive cells of the spleen red pulp such as resident macrophages (Fig. 1). In conclusion, the available data support the idea that, at least for the case of colonization of deeper tissues by serovar Typhimurium, there are subsets of bacteria that occupy various tissue microenvironments (123). This heterogeneity may reflect differences in the genetic makeup and the immune 
or polarization status of the invaded host cell, as is shown in the above-mentioned recent RNA-seq study of macrophages harboring either nongrowing or fastgrowing bacteria (115). Stochastic phenomena affecting the expression of host defenses and/or survival strategies of the pathogen after host encounter may also contribute to these heterogeneous responses.

\section{"SELF-DEFENSE" MECHANISMS ACTING IN INTRACELLULAR SALMONELLA}

The formation of persister cells ("persisters") has been shown to increase following the ingestion of serovar Typhimurium by macrophages (19). The persistent state is illustrated by tolerance to antibiotics in cells that remain viable upon exposure to these compounds while staying nonreplicative. Persisters are present in populations of exponentially growing cells and differ from antibiotic-resistant bacteria. Thus, once persisters resume growth in the absence of the antibiotic pressure, they are equally affected if subjected to new rounds of treatment with these compounds (124). In these terms, persistence represents a transient physiological state in which bacteria are positively selected when confronting the stress if they have a reduced growth rate. Such a situation is exemplified when bacterial cultures are exposed to antibiotics that act on fast-replicating bacteria such as $\beta$-lactams, quinonoles, or aminoglycosides. As mentioned above, the persistent phenotype can also be favored in pathogens inside eukaryotic cells following exposure to the intracellular environment of macrophages (19). This situation should, however, be distinguished from the selection of small-colony variants of serovar Typhimurium resistant to aminoglycosides, which are selected with stable mutations after a long residence $(>72 \mathrm{~h})$ in the intracellular niche of fibroblasts (75). At first glance, both persistence strategies increase residence in the host and constitute positive factors that promote pathogen transmissibility.

Do bacteria restrain growth intentionally to reach a persistent state? Many of the mechanisms known were first characterized in Escherichia coli, in which elevated levels of the alarmone ppGpp accumulating in response to nutritional stress play an important role $(\underline{125}, 126)$. The fact that bacteria use specific mechanisms to reach this state favors the idea of persistence as a programmed, epigenetic phenomenon with a genetic basis $(127,128)$.

Much work has been accumulated in recent years regarding the involvement of toxin-antitoxin (TA) modules in bacterial persistence and virulence $(126,129-$ 131). Most TA loci encode two antagonistic proteins, the toxin involved in inhibiting growth and the antitoxin that regulates toxin activity. The first mutation associated with increased persistence rates in E. coli was mapped to the hipAB TA locus, which coded for the HipA serine kinase that is partially phosphorylated in vivo. HipA kinase activity is required for persister formation in defined conditions (132). Recent studies show that HipA phosphorylates tRNA synthetase GltX (133), leading to inhibition of protein synthesis. This situation favors accumulation of the ppGpp alarmone following increased levels of uncharged tRNAs, a condition that stimulates the ppGpp-producing enzymes RelA and SpoT (126). Other toxins encoded in TA loci act as RNases that recognize and cleave $23 \mathrm{~S}$ rRNA, tRNAs, and either free or ribosome-bound mRNA; kinases that target elongation factor EF-Tu; or as inhibitors of DNA replication by targeting of DNA gyrase (126).

The fact that TA modules arrest bacterial growth makes them attractive candidates to contribute to pathogen persistence during infection (Table 1) (129, 130). Under these conditions, pathogen-host coexistence increases, and as a result, so does transmissibility. An increased rate of persisters in serovar Typhimuriuminfected macrophages was associated with the activity in the pathogen of as many as 14 TA loci (19). A recent study in fibroblasts demonstrated the production by nongrowing intracellular serovar Typhimurium of a series of toxins encoded by TA loci (134). This work also showed distinct responses of certain TA loci in permissive (epithelial) and nonpermissive (fibroblasts) nonphagocytic cells regarding pathogen proliferation (134). These observations suggest that the nongrowing persistence state reached by serovar Typhimurium inside fibroblasts may require the intervention of a subset of TA loci (Fig. 2D). The usage by the pathogen of multiple TA loci may reflect a "safeguard" strategy to ensure rapid arrest of growth before defenses of the infected host cell irreversibly inactivate essential pathogen functions. A recent study revealed that serovar Typhimurium can arrest growth by using an enzyme encoded in a TA system, named TacT, which acetylates amino groups of amino acids charged on tRNA molecules, having a strong effect on translation (135). This study also identified a deactylase, CobB, which removes the acetyl group to resume growth. Whether TacT and/or CobB are active in intracellular bacteria has not yet been determined.

The role played by TA loci in persistence of serovar Typhimurium and other pathogens (129) supports the widely accepted model of a programmed phenomenon. 
It is worth noting that early studies in serovar Typhimurium also provided evidence for a genetic program involved in attenuating intracellular growth inside fibroblasts (65). This program is orchestrated by defined regulators, including the two-component regulatory system PhoP-PhoQ (Fig. 2C), involved in maintenance of envelope homeostasis, and the alternative sigma factor RpoS, among others (65). Mutants lacking these regulatory proteins "overgrow" inside the infected fibroblasts when compared to the parental wild-type bacteria, a response that also occurs in vivo in stromal nonphagocytic cells and in primary intestinal fibroblasts (41, 64). Whether the growth-attenuating response directed by these regulators correlates to the intervention of some specific TA loci is at present unknown.

\section{CONCLUSIONS AND FUTURE PERSPECTIVES}

Epidemiological data point to typhoidal and nontyphoidal Salmonella serovars as pathogens that are highly transmitted from host to host. Modern in vivo technologies are providing new insights into the behavior of these bacteria in distinct host cell types, at various infection times, and in diverse tissues/organs. The bulk of new data obtained point to an unsuspected complexity and heterogeneity in the type of encounters that occur when the pathogen attacks the intestinal epithelium or when, in the case of acute infections, it disseminates to deep organs. This complexity is now registered at the single-cell level in several in vitro and in vivo infection models and needs to be integrated with the intrinsic variability in genome content among different Salmonella species, subspecies, and serovars, and even among isolates belonging to the same serovar. Most of the studies to date have focused on serovar Typhimurium, with relatively few comparable analyses in other serovars (Table 1).

Fortunately, recent studies pinpoint for the first time mutations in defined genes that alter pathogen behavior regarding persistence in the host and the ability to colonize the intestine or extraintestinal sites (136). Genome-wide expression data also exist for the colonization by intracellular serovar Typhimurium of distinct host cell types such as macrophages, epithelial cells, and fibroblasts $(64,137,138)$, and these data should be exploited at the functional level. Comparative genomics is also a powerful resource, and there is now evidence of mutations causing the emergence in immunocompromised hosts of highly adapted clones in serovars normally infecting a broad range of hosts (139). Some studies also reported mutations in defined "invasive" serovar Typhimurium clones that associate with immunedeficient and immune-competent hosts and infect with high mortality rate, especially in the sub-Saharan Africa (140).

We are therefore facing a scenario in which new molecular and cellular data are rapidly generated with modern techniques in apparently simplified models (e.g., cultured cell lines), which nonetheless exhibit marked heterogeneity. A major future goal will be to understand the basis of this heterogeneity so as to further extrapolate such knowledge to the genomic and epidemiological data. This is certainly challenging, as revealed by the still limited number of studies that attempt to join the cellular/molecular and epidemiological landscapes. Filling this gap is essential to increase our knowledge on evolution of typhoidal and nontyphoidal Salmonella serovars as intracellular bacterial pathogens, their adaptation to multiple lifestyles inside the eukaryotic cell, and how these lifestyles impact host-to-host transmissibility.

\section{ACKNOWLEDGMENTS}

We apologize for those studies that could not be cited due to space limitations. Work in our laboratories is supported by grants BIO2014-55238-R (to M.G.P.) and BIO2013-46281-P, PCIN2016-082, and BIO2016-77639-P (MINECO/FEDER) (to F.G.dP.) from the Spanish Ministry of Economy and Competitiveness and European Regional Development Fund.

\section{REFERENCES}

1. Rivera-Chávez F, Bäumler AJ. 2015. The pyromaniac inside you: Salmonella metabolism in the host gut. Annu Rev Microbiol 69:31-48. http://dx.doi.org/10.1146/annurev-micro-091014-104108.

2. LaRock DL, Chaudhary A, Miller SI. 2015. Salmonellae interactions with host processes. Nat Rev Microbiol 13:191-205. http://dx.doi.org /10.1038/nrmicro3420.

3. de Jong HK, Parry CM, van der Poll T, Wiersinga WJ. 2012. Hostpathogen interaction in invasive salmonellosis. PLoS Pathog 8:e1002933. http://dx.doi.org/10.1371/journal.ppat.1002933.

4. Graham SM. 2010. Nontyphoidal salmonellosis in Africa. Curr Opin Infect Dis 23:409-414. http://dx.doi.org/10.1097/QCO.0b013e32833 dd25d.

5. Wiesner M, Calva JJ, Bustamante VH, Pérez-Morales D, FernándezMora M, Calva E, Silva C. 2016. A multi-drug resistant Salmonella Typhimurium ST213 human-invasive strain (33676) containing the bla $a_{\mathrm{CMY}-2}$ gene on an IncF plasmid is attenuated for virulence in BALB/c mice. BMC Microbiol 16:18. http://dx.doi.org/10.1186/s12866-016 $\underline{-0633-7 .}$

6. Monack DM. 2012. Salmonella persistence and transmission strategies. Curr Opin Microbiol 15:100-107 http://dx.doi.org/10.1016/j.mib.2011 .10 .013 .

7. Gopinath S, Carden S, Monack D. 2012. Shedding light on Salmonella carriers. Trends Microbiol 20:320-327 http://dx.doi.org/10.1016/j.tim .2012 .04 .004 .

8. Ledingham JCG, Arkwright JA. 1912. The Carrier Problem in Infectious Diseases. Edward Arnold, London, United Kingdom.

9. Søndberg E, Jelsbak L. 2016. Salmonella Typhimurium undergoes distinct genetic adaption during chronic infections of mice. BMC Microbiol 16:30. http://dx.doi.org/10.1186/s12866-016-0646-2. 
10. Lawley TD, Chan K, Thompson LJ, Kim CC, Govoni GR, Monack DM. 2006. Genome-wide screen for Salmonella genes required for longterm systemic infection of the mouse. PLoS Pathog 2:e11. http://dx.doi .org/10.1371/journal.ppat.0020011.

11. Takeuchi A. 1967. Electron microscope studies of experimental Salmonella infection. I. Penetration into the intestinal epithelium by Salmonella typhimurium. Am J Pathol 50:109-136.

12. Kihlström E, Edebo L. 1976. Association of viable and inactivated Salmonella typhimurium 395 MS and MR 10 with HeLa cells. Infect Immun 14:851-857.

13. Giannella RA, Washington O, Gemski P, Formal SB. 1973. Invasion of HeLa cells by Salmonella typhimurium: a model for study of invasiveness of Salmonella. J Infect Dis 128:69-75. http://dx.doi.org/10.1093/infdis/128.1.69. 14. Garcia-del Portillo F, Finlay BB. 1995. Targeting of Salmonella typhimurium to vesicles containing lysosomal membrane glycoproteins bypasses compartments with mannose 6-phosphate receptors. J Cell Biol 129:81-97. http://dx.doi.org/10.1083/jcb.129.1.81.

15. Brumell JH, Perrin AJ, Goosney DL, Finlay BB. 2002. Microbial pathogenesis: new niches for Salmonella. Curr Biol 12:R15-R17. http://dx.doi.org/10.1016/S0960-9822(01)00640-6.

16. Scanu T, Spaapen RM, Bakker JM, Pratap CB, Wu LE, Hofland I, Broeks A, Shukla VK, Kumar M, Janssen H, Song JY, Neefjes-Borst EA, te Riele H, Holden DW, Nath G, Neefjes J. 2015. Salmonella manipulation of host signaling pathways provokes cellular transformation associated with gallbladder carcinoma. Cell Host Microbe 17:763-774. http://dx.doi.org/10.1016/i.chom.2015.05.002.

17. Forbester JL, Goulding D, Vallier L, Hannan N, Hale C, Pickard D, Mukhopadhyay S, Dougan G. 2015. Interaction of Salmonella enterica serovar Typhimurium with intestinal organoids derived from human induced pluripotent stem cells. Infect Immun 83:2926-2934. http://dx.doi .org/10.1128/IAI.00161-15.

18. Zhang YG, Wu S, Xia Y, Sun J. 2014. Salmonella-infected cryptderived intestinal organoid culture system for host-bacterial interactions. Physiol Rep 2:e12147. http://dx.doi.org/10.14814/phy2.12147.

19. Helaine S, Cheverton AM, Watson KG, Faure LM, Matthews SA, Holden DW. 2014. Internalization of Salmonella by macrophages induces formation of nonreplicating persisters. Science 343:204-208. http://dx .doi.org/10.1126/science.1244705.

20. Knodler LA. 2015. Salmonella enterica: living a double life in epithelial cells. Curr Opin Microbiol 23:23-31. http://dx.doi.org/10.1016/j.mib .2014 .10 .010 .

21. Malik-Kale P, Winfree S, Steele-Mortimer O. 2012. The bimodal lifestyle of intracellular Salmonella in epithelial cells: replication in the cytosol obscures defects in vacuolar replication. PLoS One 7:e38732. http://dx.doi.org/10.1371/journal.pone.0038732.

22. Figueira R, Holden DW. 2012. Functions of the Salmonella pathogenicity island 2 (SPI-2) type III secretion system effectors. Microbiology 158:1147-1161. http://dx.doi.org/10.1099/mic.0.058115-0.

23. Moest TP, Méresse S. 2013. Salmonella T3SSs: successful mission of the secret(ion) agents. Curr Opin Microbiol 16:38-44. http://dx.doi.org 110.1016/j.mib.2012.11.006.

24. Galán JE, Wolf-Watz H. 2006. Protein delivery into eukaryotic cells by type III secretion machines. Nature 444:567-573. http://dx.doi.org /10.1038/nature05272.

25. Patel JC, Galán JE. 2005. Manipulation of the host actin cytoskeleton by Salmonella - all in the name of entry. Curr Opin Microbiol 8:10-15. http://dx.doi.org/10.1016/i.mib.2004.09.001.

26. Schlumberger MC, Hardt WD. 2005. Triggered phagocytosis by Salmonella: bacterial molecular mimicry of RhoGTPase activation/ deactivation. Curr Top Microbiol Immunol 291:29-42. http://dx.doi.org /10.1007/3-540-27511-8_3.

27. Agbor TA, McCormick BA. 2011. Salmonella effectors: important players modulating host cell function during infection. Cell Microbiol 13:1858-1869. http://dx.doi.org/10.1111/j.1462-5822.2011.01701.x.
28. Aiastui A, Pucciarelli MG, García-del Portillo F. 2010. Salmonella enterica serovar Typhimurium invades fibroblasts by multiple routes differing from the entry into epithelial cells. Infect Immun 78:2700-2713. http://dx.doi.org/10.1128/IAI.01389-09.

29. Velge P, Wiedemann A, Rosselin M, Abed N, Boumart Z, Chaussé AM, Grépinet O, Namdari F, Roche SM, Rossignol A, Virlogeux-Payant I. 2012. Multiplicity of Salmonella entry mechanisms, a new paradigm for Salmonella pathogenesis. MicrobiologyOpen 1:243-258. http://dx.doi .org/10.1002/mbo3.28.

30. Mijouin L, Rosselin M, Bottreau E, Pizarro-Cerda J, Cossart P, Velge P, Wiedemann A. 2012. Salmonella enteritidis Rck-mediated invasion requires activation of Rac1, which is dependent on the class I PI 3-kinases-Akt signaling pathway. FASEB J 26:1569-1581. http://dx.doi .org/10.1096/fi.11-189647.

31. Rosselin M, Abed N, Virlogeux-Payant I, Bottreau E, Sizaret PY, Velge P, Wiedemann A. 2011. Heterogeneity of type III secretion system (T3SS)-1-independent entry mechanisms used by Salmonella Enteritidis to invade different cell types. Microbiology 157:839-847. http://dx.doi.org /10.1099/mic.0.044941-0.

32. Desin TS, Lam PK, Koch B, Mickael C, Berberov E, Wisner AL, Townsend HG, Potter AA, Köster W. 2009. Salmonella enterica serovar Enteritidis pathogenicity island 1 is not essential for but facilitates rapid systemic spread in chickens. Infect Immun 77:2866-2875. http://dx.doi .org/10.1128/IAI.00039-09.

33. Rychlik I, Karasova D, Sebkova A, Volf J, Sisak F, Havlickova H, Kummer V, Imre A, Szmolka A, Nagy B. 2009. Virulence potential of five major pathogenicity islands (SPI-1 to SPI-5) of Salmonella enterica serovar Enteritidis for chickens. BMC Microbiol 9:268. http://dx.doi.org/10.1186 11471-2180-9-268.

34. Jones MA, Wigley P, Page KL, Hulme SD, Barrow PA. 2001. Salmonella enterica serovar Gallinarum requires the Salmonella pathogenicity island 2 type III secretion system but not the Salmonella pathogenicity island 1 type III secretion system for virulence in chickens. Infect Immun 69:5471-5476. http://dx.doi.org/10.1128/IAI.69.9.5471-5476.2001.

35. Rathman M, Barker LP, Falkow S. 1997. The unique trafficking pattern of Salmonella typhimurium-containing phagosomes in murine macrophages is independent of the mechanism of bacterial entry. Infect Immun 65:1475-1485.

36. Drecktrah D, Knodler LA, Ireland R, Steele-Mortimer O. 2006. The mechanism of Salmonella entry determines the vacuolar environment and intracellular gene expression. Traffic 7:39-51. http://dx.doi.org/10.1111 j.1600-0854.2005.00360.x.

37. Valdez Y, Ferreira RB, Finlay BB. 2009. Molecular mechanisms of Salmonella virulence and host resistance. Curr Top Microbiol Immunol 337:93-127. http://dx.doi.org/10.1007/978-3-642-01846-6_4.

38. Fields PI, Swanson RV, Haidaris CG, Heffron F. 1986. Mutants of Salmonella typhimurium that cannot survive within the macrophage are avirulent. Proc Natl Acad Sci U S A 83:5189-5193. http://dx.doi.org 110.1073/pnas.83.14.5189.

39. Malik-Kale P, Jolly CE, Lathrop S, Winfree S, Luterbach C, SteeleMortimer O. 2011. Salmonella-at home in the host cell. Front Microbiol 2:125. http://dx.doi.org/10.3389/fmicb.2011.00125.

40. Bakowski MA, Braun V, Brumell JH. 2008. Salmonella-containing vacuoles: directing traffic and nesting to grow. Traffic 9:2022-2031. http://dx.doi.org/10.1111/j.1600-0854.2008.00827.x.

41. García-del Portillo F, Núñez-Hernández C, Eisman B, Ramos-Vivas J. 2008. Growth control in the Salmonella-containing vacuole. Curr Opin Microbiol 11:46-52. http://dx.doi.org/10.1016/j.mib.2008.01.001.

42. Holden DW. 2002. Trafficking of the Salmonella vacuole in macrophages. Traffic 3:161-169. http://dx.doi.org/10.1034/j.1600-0854.2002 .030301.x.

43. Steele-Mortimer O. 2008. The Salmonella-containing vacuole: moving with the times. Curr Opin Microbiol 11:38-45. http://dx.doi.org/10.1016 j.mib.2008.01.002. 
44. Ramsden AE, Holden DW, Mota LJ. 2007. Membrane dynamics and spatial distribution of Salmonella-containing vacuoles. Trends Microbiol 15:516-524. http://dx.doi.org/10.1016/j.tim.2007.10.002.

45. Zhao Y, Gorvel JP, Méresse S. 2016. Effector proteins support the asymmetric apportioning of Salmonella during cytokinesis. Virulence 7:669-678. http://dx.doi.org/10.1080/21505594.2016.1173298.

46. van der Heijden J, Finlay BB. 2012. Type III effector-mediated processes in Salmonella infection. Future Microbiol 7:685-703. http://dx.doi .org/10.2217/fmb.12.49.

47. Liss V, Hensel M. 2015. Take the tube: remodelling of the endosomal system by intracellular Salmonella enterica. Cell Microbiol 17:639-647. http://dx.doi.org/10.1111/cmi.12441.

48. Jackson LK, Nawabi P, Hentea C, Roark EA, Haldar K. 2008. The Salmonella virulence protein SifA is a G protein antagonist. Proc Natl Acad Sci U S A 105:14141-14146. http://dx.doi.org/10.1073/pnas .0801872105 .

49. D’Costa VM, Braun V, Landekic M, Shi R, Proteau A, McDonald L, Cygler M, Grinstein S, Brumell JH. 2015. Salmonella disrupts host endocytic trafficking by SopD2-mediated inhibition of Rab7. Cell Rep 12:1508-1518. http://dx.doi.org/10.1016/j.celrep.2015.07.063.

50. Spanò S, Galán JE. 2012. A Rab32-dependent pathway contributes to Salmonella typhi host restriction. Science 338:960-963. http://dx.doi.org /10.1126/science.1229224.

51. Spanò S, Liu X, Galán JE. 2011. Proteolytic targeting of Rab29 by an effector protein distinguishes the intracellular compartments of humanadapted and broad-host Salmonella. Proc Natl Acad Sci U S A 108: 18418-18423. http://dx.doi.org/10.1073/pnas.1111959108.

52. Garcia-del Portillo F, Zwick MB, Leung KY, Finlay BB. 1993. Salmonella induces the formation of filamentous structures containing lysosomal membrane glycoproteins in epithelial cells. Proc Natl Acad Sci U S A 90:10544-10548. http://dx.doi.org/10.1073/pnas.90.22.10544.

53. Schroeder N, Mota LJ, Méresse S. 2011. Salmonella-induced tubular networks. Trends Microbiol 19:268-277. http://dx.doi.org/10.1016/j.tim 2011.01.006.

54. Stein MA, Leung KY, Zwick M, Garcia-del Portillo F, Finlay BB. 1996. Identification of a Salmonella virulence gene required for formation of filamentous structures containing lysosomal membrane glycoproteins within epithelial cells. Mol Microbiol 20:151-164. http://dx.doi.org /10.1111/j.1365-2958.1996.tb02497.x.

55. Freeman JA, Ohl ME, Miller SI. 2003. The Salmonella enterica serovar Typhimurium translocated effectors SseJ and SifB are targeted to the Salmonella-containing vacuole. Infect Immun 71:418-427. http://dx.doi .org/10.1128/IAI.71.1.418-427.2003.

56. McEwan DG, Richter B, Claudi B, Wigge C, Wild P, Farhan H, McGourty K, Coxon FP, Franz-Wachtel M, Perdu B, Akutsu M, Habermann A, Kirchof A, Helfrich MH, Odgren PR, Van Hul W, Frangakis AS, Rajalingam K, Macek B, Holden DW, Bumann D, Dikic I. 2015. PLEKHM1 regulates Salmonella-containing vacuole biogenesis and infection. Cell Host Microbe 17:58-71. http://dx.doi.org/10.1016/j.chom.2014.11.011.

57. López-Montero N, Ramos-Marquès E, Risco C, García-Del Portillo F. 2016. Intracellular Salmonella induces aggrephagy of host endomembranes in persistent infections. Autophagy 12:1886-1901. http://dx.doi .org/10.1080/15548627.2016.1208888.

58. Knodler LA, Nair V, Steele-Mortimer O. 2014. Quantitative assessment of cytosolic Salmonella in epithelial cells. PLoS One 9:e84681. http://dx.doi.org/10.1371/journal.pone.0084681.

59. Knodler LA, Vallance BA, Celli J, Winfree S, Hansen B, Montero M, Steele-Mortimer O. 2010. Dissemination of invasive Salmonella via bacterial-induced extrusion of mucosal epithelia. Proc Natl Acad Sci U S A 107:17733-17738. http://dx.doi.org/10.1073/pnas.1006098107.

60. Menendez A, Arena ET, Guttman JA, Thorson L, Vallance BA, Vogl W, Finlay BB. 2009. Salmonella infection of gallbladder epithelial cells drives local inflammation and injury in a model of acute typhoid fever. J Infect Dis 200:1703-1713. http://dx.doi.org/10.1086/646608.
61. Crowley SM, Knodler LA, Vallance BA. 2016. Salmonella and the inflammasome: battle for intracellular dominance. Curr Top Microbiol Immunol 397:43-67. http://dx.doi.org/10.1007/978-3-319-41171-2_3. 62. Sellin ME, Maslowski KM, Maloy KJ, Hardt WD. 2015. Inflammasomes of the intestinal epithelium. Trends Immunol 36:442-450. http:// dx.doi.org/10.1016/j.it.2015.06.002.

63. Sellin ME, Müller AA, Felmy B, Dolowschiak T, Diard M, Tardivel A, Maslowski KM, Hardt WD. 2014. Epithelium-intrinsic NAIP/NLRC4 inflammasome drives infected enterocyte expulsion to restrict Salmonella replication in the intestinal mucosa. Cell Host Microbe 16:237-248. http://dx.doi.org/10.1016/j.chom.2014.07.001.

64. Núñez-Hernández C, Tierrez A, Ortega AD, Pucciarelli MG, Godoy M, Eisman B, Casadesús J, García-del Portillo F. 2013. Genome expression analysis of nonproliferating intracellular Salmonella enterica serovar Typhimurium unravels an acid $\mathrm{pH}$-dependent $\mathrm{PhoP}-\mathrm{PhoQ}$ response essential for dormancy. Infect Immun 81:154-165. http://dx.doi.org /10.1128/IAI.01080-12.

65. Cano DA, Martínez-Moya M, Pucciarelli MG, Groisman EA, Casadesús J, García-Del Portillo F. 2001. Salmonella enterica serovar Typhimurium response involved in attenuation of pathogen intracellular proliferation. Infect Immun 69:6463-6474. http://dx.doi.org/10.1128 IIAI.69.10.6463-6474.2001.

66. Garcia-del Portillo F, Stein MA, Finlay BB. 1997. Release of lipopolysaccharide from intracellular compartments containing Salmonella typhimurium to vesicles of the host epithelial cell. Infect Immun 65:24-34. 67. Ruby T, McLaughlin L, Gopinath S, Monack D. 2012. Salmonella's long-term relationship with its host. FEMS Microbiol Rev 36:600-615. http://dx.doi.org/10.1111/j.1574-6976.2012.00332.x.

68. Lawley TD, Bouley DM, Hoy YE, Gerke C, Relman DA, Monack DM. 2008. Host transmission of Salmonella enterica serovar Typhimurium is controlled by virulence factors and indigenous intestinal microbiota. Infect Immun 76:403-416. http://dx.doi.org/10.1128/IAI.01189-07.

69. Monack DM, Bouley DM, Falkow S. 2004. Salmonella typhimurium persists within macrophages in the mesenteric lymph nodes of chronically infected $\mathrm{Nramp} 1^{+/+}$mice and can be reactivated by IFN $\gamma$ neutralization. J Exp Med 199:231-241. http://dx.doi.org/10.1084/jem.20031319.

70. Eisele NA, Ruby T, Jacobson A, Manzanillo PS, Cox JS, Lam L, Mukundan L, Chawla A, Monack DM. 2013. Salmonella require the fatty acid regulator PPAR $\delta$ for the establishment of a metabolic environment essential for long-term persistence. Cell Host Microbe 14:171-182. http://dx.doi.org/10.1016/i.chom.2013.07.010.

71. Gonzalez-Escobedo G, Gunn JS. 2013. Gallbladder epithelium as a niche for chronic Salmonella carriage. Infect Immun 81:2920-2930. http://dx.doi.org/10.1128/IAI.00258-13.

72. Gunn JS, Marshall JM, Baker S, Dongol S, Charles RC, Ryan ET. 2014. Salmonella chronic carriage: epidemiology, diagnosis, and gallbladder persistence. Trends Microbiol 22:648-655. http://dx.doi.org /10.1016/j.tim.2014.06.007.

73. Bäumler AJ, Winter SE, Thiennimitr P, Casadesús J. 2011. Intestinal and chronic infections: Salmonella lifestyles in hostile environments. Environ Microbiol Rep 3:508-517. http://dx.doi.org/10.1111/j.1758 $\underline{-2229.2011 .00242 . \mathrm{x}}$.

74. Gonzalez-Escobedo G, Gunn JS. 2013. Identification of Salmonella enterica serovar Typhimurium genes regulated during biofilm formation on cholesterol gallstone surfaces. Infect Immun 81:3770-3780. http://dx .doi.org/10.1128/IAI.00647-13.

75. Cano DA, Pucciarelli MG, Martínez-Moya M, Casadesús J, García-del Portillo F. 2003. Selection of small-colony variants of Salmonella enterica serovar Typhimurium in nonphagocytic eucaryotic cells. Infect Immun 71:3690-3698. http://dx.doi.org/10.1128/IAI.71.7.3690-3698.2003.

76. Proctor RA, Kriegeskorte A, Kahl BC, Becker K, Löffler B, Peters G. 2014. Staphylococcus aureus small colony variants (SCVs): a road map for the metabolic pathways involved in persistent infections. Front Cell Infect Microbiol 4:99. http://dx.doi.org/10.3389/fcimb.2014.00099. 
77. George AS, Salas González I, Lorca GL, Teplitski M. 2015. Contribution of the Salmonella enterica KdgR regulon to persistence of the pathogen in vegetable soft rots. Appl Environ Microbiol 82:1353-1360. http://dx.doi.org/10.1128/AEM.03355-15.

78. Popp J, Noster J, Busch K, Kehl A, Zur Hellen G, Hensel M. 2015. Role of host cell-derived amino acids in nutrition of intracellular Salmonella enterica. Infect Immun 83:4466-4475. http://dx.doi.org/10.1128 IIAI.00624-15.

79. Steeb B, Claudi B, Burton NA, Tienz P, Schmidt A, Farhan H, Mazé A, Bumann D. 2013. Parallel exploitation of diverse host nutrients enhances Salmonella virulence. PLoS Pathog 9:e1003301. http://dx.doi.org /10.1371/journal.ppat.1003301.

80. Bowden SD, Rowley G, Hinton JC, Thompson A. 2009. Glucose and glycolysis are required for the successful infection of macrophages and mice by Salmonella enterica serovar Typhimurium. Infect Immun 77:3117-3126. http://dx.doi.org/10.1128/IAI.00093-09.

81. Bowden SD, Hopper-Chidlaw AC, Rice CJ, Ramachandran VK, Kelly DJ, Thompson A. 2014. Nutritional and metabolic requirements for the infection of HeLa cells by Salmonella enterica serovar Typhimurium. PLoS One 9:e96266. http://dx.doi.org/10.1371/journal.pone.0096266.

82. Barat S, Steeb B, Mazé A, Bumann D. 2012. Extensive in vivo resilience of persistent Salmonella. PLoS One 7:e42007. http://dx.doi.org /10.1371/journal.pone.0042007.

83. Fang FC, Frawley ER, Tapscott T, Vázquez-Torres A. 2016. Bacterial stress responses during host infection. Cell Host Microbe 20:133-143. http://dx.doi.org/10.1016/i.chom.2016.07.009.

84. Wileman T. 2013. Autophagy as a defence against intracellular pathogens. Essays Biochem 55:153-163. http://dx.doi.org/10.1042 /bse0550153.

85. Jo EK, Yuk JM, Shin DM, Sasakawa C. 2013. Roles of autophagy in elimination of intracellular bacterial pathogens. Front Immunol 4:97. http://dx.doi.org/10.3389/fimmu.2013.00097.

86. Steele S, Brunton J, Kawula T. 2015. The role of autophagy in intracellular pathogen nutrient acquisition. Front Cell Infect Microbiol 5:51. http://dx.doi.org/10.3389/fcimb.2015.00051.

87. Winchell CG, Steele S, Kawula T, Voth DE. 2016. Dining in: intracellular bacterial pathogen interplay with autophagy. Curr Opin Microbiol 29:9-14. http://dx.doi.org/10.1016/j.mib.2015.09.004.

88. Birmingham CL, Brumell JH. 2006. Autophagy recognizes intracellular Salmonella enterica serovar Typhimurium in damaged vacuoles. Autophagy 2:156-158. http://dx.doi.org/10.4161/auto.2825.

89. Huett A, Heath RJ, Begun J, Sassi SO, Baxt LA, Vyas JM, Goldberg MB, Xavier RJ. 2012. The LRR and RING domain protein LRSAM1 is an E3 ligase crucial for ubiquitin-dependent autophagy of intracellular Salmonella Typhimurium. Cell Host Microbe 12:778-790. http://dx.doi .org/10.1016/j.chom.2012.10.019.

90. Spinnenhirn V, Farhan H, Basler M, Aichem A, Canaan A, Groettrup M. 2014. The ubiquitin-like modifier FAT10 decorates autophagytargeted Salmonella and contributes to Salmonella resistance in mice. J Cell Sci 127:4883-4893. http://dx.doi.org/10.1242/jcs.152371.

91. Yu HB, Croxen MA, Marchiando AM, Ferreira RB, Cadwell K, Foster LJ, Finlay BB. 2014. Autophagy facilitates Salmonella replication in HeLa cells. mBio 5:e00865-e14. http://dx.doi.org/10.1128/mBio.00865-14.

92. Wessling-Resnick M. 2015. Nramp1 and other transporters involved in metal withholding during infection. J Biol Chem 290:18984-18990. http://dx.doi.org/10.1074/jbc.R115.643973.

93. Vassiloyanakopoulos AP, Okamoto S, Fierer J. 1998. The crucial role of polymorphonuclear leukocytes in resistance to Salmonella dublin infections in genetically susceptible and resistant mice. Proc Natl Acad Sci U S A 95:7676-7681. http://dx.doi.org/10.1073/pnas.95.13.7676.

94. Segal BH, Grimm MJ, Khan AN, Han W, Blackwell TS. 2012. Regulation of innate immunity by NADPH oxidase. Free Radic Biol Med 53:72-80. http://dx.doi.org/10.1016/j.freeradbiomed.2012.04.022.
95. Bogdan C. 2015. Nitric oxide synthase in innate and adaptive immunity: an update. Trends Immunol 36:161-178. http://dx.doi.org /10.1016/j.it.2015.01.003.

96. Puri AW, Broz P, Shen A, Monack DM, Bogyo M. 2012. Caspase-1 activity is required to bypass macrophage apoptosis upon Salmonella infection. Nat Chem Biol 8:745-747. http://dx.doi.org/10.1038/nchembio .1023 .

97. Lara-Tejero M, Sutterwala FS, Ogura Y, Grant EP, Bertin J, Coyle AJ, Flavell RA, Galán JE. 2006. Role of the caspase-1 inflammasome in Salmonella typhimurium pathogenesis. J Exp Med 203:1407-1412. http://dx.doi.org/10.1084/jem.20060206.

98. Miao EA, Rajan JV. 2011. Salmonella and caspase-1: a complex interplay of detection and evasion. Front Microbiol 2:85. http://dx.doi.org /10.3389/fmicb.2011.00085.

99. Broz P, Newton K, Lamkanfi M, Mariathasan S, Dixit VM, Monack DM. 2010. Redundant roles for inflammasome receptors NLRP3 and NLRC4 in host defense against Salmonella. J Exp Med 207:1745-1755. http://dx.doi.org/10.1084/jem.20100257.

100. Birmingham CL, Smith AC, Bakowski MA, Yoshimori T, Brumell JH. 2006. Autophagy controls Salmonella infection in response to damage to the Salmonella-containing vacuole. J Biol Chem 281:11374-11383. http://dx.doi.org/10.1074/jbc.M509157200.

101. Kreibich S, Emmenlauer M, Fredlund J, Rämö P, Münz C, Dehio C, Enninga J, Hardt WD. 2015. Autophagy proteins promote repair of endosomal membranes damaged by the Salmonella type three secretion system 1. Cell Host Microbe 18:527-537. http://dx.doi.org/10.1016 /j.chom.2015.10.015.

102. Benjamin JL, Sumpter R Jr, Levine B, Hooper LV. 2013. Intestinal epithelial autophagy is essential for host defense against invasive bacteria. Cell Host Microbe 13:723-734. http://dx.doi.org/10.1016/j.chom.2013 .05 .004 .

103. Shiloh MU, MacMicking JD, Nicholson S, Brause JE, Potter S, Marino M, Fang F, Dinauer M, Nathan C. 1999. Phenotype of mice and macrophages deficient in both phagocyte oxidase and inducible nitric oxide synthase. Immunity 10:29-38. http://dx.doi.org/10.1016/S1074 -7613(00)80004-7.

104. Boyle KB, Randow F. 2013. The role of 'eat-me' signals and autophagy cargo receptors in innate immunity. Curr Opin Microbiol 16:339-348. http://dx.doi.org/10.1016/j.mib.2013.03.010.

105. Begun J, Lassen KG, Jijon HB, Baxt LA, Goel G, Heath RJ, Ng A, Tam JM, Kuo SY, Villablanca EJ, Fagbami L, Oosting M, Kumar V, Schenone M, Carr SA, Joosten LA, Vyas JM, Daly MJ, Netea MG, Brown GD, Wijmenga C, Xavier RJ. 2015. Integrated genomics of Crohn's disease risk variant identifies a role for CLEC12A in antibacterial autophagy. Cell Rep 11:1905-1918. http://dx.doi.org/10.1016/j.celrep.2015.05.045. 106. Miller SI, Chaudhary A. 2016. A cellular GWAS approach to define human variation in cellular pathways important to inflammation. Pathogens 5:E39. http://dx.doi.org/10.3390/pathogens5020039.

107. Kuijl C, Savage ND, Marsman M, Tuin AW, Janssen L, Egan DA, Ketema M, van den Nieuwendijk R, van den Eeden SJ, Geluk A, Poot A, van der Marel G, Beijersbergen RL, Overkleeft H, Ottenhoff TH, Neefjes J. 2007. Intracellular bacterial growth is controlled by a kinase network around PKB/AKT1. Nature 450:725-730. http://dx.doi .org/10.1038/nature06345.

108. Wild P, Farhan H, McEwan DG, Wagner S, Rogov VV, Brady NR, Richter B, Korac J, Waidmann O, Choudhary C, Dötsch V, Bumann D, Dikic I. 2011. Phosphorylation of the autophagy receptor optineurin restricts Salmonella growth. Science 333:228-233. http://dx.doi.org /10.1126/science.1205405.

109. Thurston TL, Boyle KB, Allen M, Ravenhill BJ, Karpiyevich M, Bloor S, Kaul A, Noad J, Foeglein A, Matthews SA, Komander D, Bycroft M, Randow F. 2016. Recruitment of TBK1 to cytosol-invading Salmonella induces WIPI2-dependent antibacterial autophagy. EMBO J 35:1779-1792. http://dx.doi.org/10.15252/embj.201694491. 
110. Radtke AL, Delbridge LM, Balachandran S, Barber GN, O'Riordan MX. 2007. TBK1 protects vacuolar integrity during intracellular bacterial infection. PLoS Pathog 3:e29. http://dx.doi.org/10.1371/journal.ppat .0030029

111. Osborne SE, Tuinema BR, Mok MC, Lau PS, Bui NK, Tomljenovic-Berube AM, Vollmer W, Zhang K, Junop M, Coombes BK. 2012. Characterization of DalS, an ATP-binding cassette transporter for D-alanine, and its role in pathogenesis in Salmonella enterica. J Biol Chem 287:15242-15250. http://dx.doi.org/10.1074/jbc.M112 .348227 .

112. Tuinema BR, Reid-Yu SA, Coombes BK. 2014. Salmonella evades D-amino acid oxidase to promote infection in neutrophils. mBio 5:e01886. http://dx.doi.org/10.1128/mBio.01886-14.

113. Westermann AJ, Förstner KU, Amman F, Barquist L, Chao Y, Schulte LN, Müller L, Reinhardt R, Stadler PF, Vogel J. 2016. Dual RNAseq unveils noncoding RNA functions in host-pathogen interactions. Nature 529:496-501. http://dx.doi.org/10.1038/nature16547.

114. Saliba AE, Westermann AJ, Gorski SA, Vogel J. 2014. Single-cell RNA-seq: advances and future challenges. Nucleic Acids Res 42:88458860. http://dx.doi.org/10.1093/nar/gku555.

115. Saliba AE, Li L, Westermann AJ, Appenzeller S, Stapels DA, Schulte LN, Helaine S, Vogel J. 2016. Single-cell RNA-seq ties macrophage polarization to growth rate of intracellular Salmonella. Nat Microbiol 2:16206. http://dx.doi.org/10.1038/nmicrobiol.2016.206.

116. Watson KG, Holden DW. 2010. Dynamics of growth and dissemination of Salmonellain vivo. Cell Microbiol 12:1389-1397. http://dx.doi .org/10.1111/j.1462-5822.2010.01511.x.

117. Gog JR, Murcia A, Osterman N, Restif O, McKinley TJ, Sheppard M, Achouri S, Wei B, Mastroeni P, Wood JL, Maskell DJ, Cicuta P, Bryant CE. 2012. Dynamics of Salmonella infection of macrophages at the single cell level. J R Soc Interface 9:2696-2707. http://dx.doi.org/10.1098 Irsif.2012.0163.

118. Richter-Dahlfors A, Buchan AM, Finlay BB. 1997. Murine salmonellosis studied by confocal microscopy: Salmonella typhimurium resides intracellularly inside macrophages and exerts a cytotoxic effect on phagocytes in vivo. J Exp Med 186:569-580. http://dx.doi.org/10.1084/jem .186 .4 .569 .

119. Salcedo SP, Noursadeghi M, Cohen J, Holden DW. 2001. Intracellular replication of Salmonella typhimurium strains in specific subsets of splenic macrophages in vivo. Cell Microbiol 3:587-597. http://dx.doi.org /10.1046/j.1462-5822.2001.00137.x.

120. Mastroeni P, Grant A, Restif O, Maskell D. 2009. A dynamic view of the spread and intracellular distribution of Salmonella enterica. Nat Rev Microbiol 7:73-80. http://dx.doi.org/10.1038/nrmicro $\underline{2034}$.

121. Claudi B, Spröte P, Chirkova A, Personnic N, Zankl J, Schürmann N, Schmidt A, Bumann D. 2014. Phenotypic variation of Salmonella in host tissues delays eradication by antimicrobial chemotherapy. Cell 158:722733. http://dx.doi.org/10.1016/j.cell.2014.06.045.

122. Burton NA, Schürmann N, Casse O, Steeb AK, Claudi B, Zankl J, Schmidt A, Bumann D. 2014. Disparate impact of oxidative host defenses determines the fate of Salmonella during systemic infection in mice. Cell Host Microbe 15:72-83. http://dx.doi.org/10.1016/j.chom .2013 .12 .006 .

123. Bumann D. 2015. Heterogeneous host-pathogen encounters: act locally, think globally. Cell Host Microbe 17:13-19. http://dx.doi.org /10.1016/i.chom.2014.12.006.

124. Gerdes K, Maisonneuve E. 2012. Bacterial persistence and toxinantitoxin loci. Annu Rev Microbiol 66:103-123. http://dx.doi.org/10.1146 lannurev-micro-092611-150159.

125. Hauryliuk V, Atkinson GC, Murakami KS, Tenson T, Gerdes K. 2015. Recent functional insights into the role of (p)ppGpp in bacterial physiology. Nat Rev Microbiol 13:298-309. http://dx.doi.org/10.1038 Inrmicro3448.
126. Maisonneuve E, Gerdes K. 2014. Molecular mechanisms underlying bacterial persisters. Cell 157:539-548. http://dx.doi.org/10.1016/j.cell .2014 .02 .050 .

127. Kussell E, Leibler S. 2005. Phenotypic diversity, population growth, and information in fluctuating environments. Science 309:2075-2078. http://dx.doi.org/10.1126/science.1114383.

128. Kussell E, Kishony R, Balaban NQ, Leibler S. 2005. Bacterial persistence: a model of survival in changing environments. Genetics 169: 1807-1814. http://dx.doi.org/10.1534/genetics.104.035352.

129. Lobato-Márquez D, Díaz-Orejas R, García-Del Portillo F. 2016. Toxin-antitoxins and bacterial virulence. FEMS Microbiol Rev 40:592609. http://dx.doi.org/10.1093/femsre/fuw022.

130. Helaine S, Kugelberg E. 2014. Bacterial persisters: formation, eradication, and experimental systems. Trends Microbiol 22:417-424. http://dx.doi.org/10.1016/j.tim.2014.03.008.

131. Page R, Peti W. 2016. Toxin-antitoxin systems in bacterial growth arrest and persistence. Nat Chem Biol 12:208-214. http://dx.doi.org /10.1038/nchembio.2044.

132. Correia FF, D’Onofrio A, Rejtar T, Li L, Karger BL, Makarova K, Koonin EV, Lewis K. 2006. Kinase activity of overexpressed HipA is required for growth arrest and multidrug tolerance in Escherichia coli. J Bacteriol 188:8360-8367. http://dx.doi.org/10.1128/JB.01237-06.

133. Germain E, Castro-Roa D, Zenkin N, Gerdes K. 2013. Molecular mechanism of bacterial persistence by HipA. Mol Cell 52:248-254. http://dx.doi.org/10.1016/j.molcel.2013.08.045.

134. Lobato-Márquez D, Moreno-Córdoba I, Figueroa V, Díaz-Orejas R, García-del Portillo F. 2015. Distinct type I and type II toxin-antitoxin modules control Salmonella lifestyle inside eukaryotic cells. Sci Rep 5:9374. http://dx.doi.org/10.1038/srep09374.

135. Cheverton AM, Gollan B, Przydacz M, Wong CT, Mylona A, Hare SA, Helaine S. 2016. A Salmonella toxin promotes persister formation through acetylation of tRNA. Mol Cell 63:86-96. http://dx.doi .org/10.1016/j.molcel.2016.05.002.

136. Nuccio SP, Bäumler AJ. 2014. Comparative analysis of Salmonella genomes identifies a metabolic network for escalating growth in the inflamed gut. mBio 5:e00929-e14. http://dx.doi.org/10.1128/mBio.00929 $\underline{-14}$.

137. Srikumar S, Kröger C, Hébrard M, Colgan A, Owen SV, Sivasankaran SK, Cameron AD, Hokamp K, Hinton JC. 2015. RNA-seq brings new insights to the intra-macrophage transcriptome of Salmonella Typhimurium. PLoS Pathog 11:e1005262. http://dx.doi.org/10.1371/journal .ppat.1005262.

138. Hautefort I, Thompson A, Eriksson-Ygberg S, Parker ML, Lucchini S, Danino V, Bongaerts RJ, Ahmad N, Rhen M, Hinton JC. 2008. During infection of epithelial cells Salmonella enterica serovar Typhimurium undergoes a time-dependent transcriptional adaptation that results in simultaneous expression of three type 3 secretion systems. Cell Microbiol 10:958-984. http://dx.doi.org/10.1111/j.1462-5822.2007.01099.x.

139. Klemm EJ, Gkrania-Klotsas E, Hadfield J, Forbester JL, Harris SR, Hale C, Heath JN, Wileman T, Clare S, Kane L, Goulding D, Otto TD, Kay S, Doffinger R, Cooke FJ, Carmichael A, Lever AML, Parkhill J, MacLennan CA, Kumararatne D, Dougan G, Kingsley RA. 2016. Emergence of host-adapted Salmonella Enteritidis through rapid evolution in an immunocompromised host. Nat Microbiol 1:15023. http://dx.doi.org /10.1038/nmicrobiol.2015.23.

140. Okoro CK, Barquist L, Connor TR, Harris SR, Clare S, Stevens MP, Arends MJ, Hale C, Kane L, Pickard DJ, Hill J, Harcourt K, Parkhill J, Dougan G, Kingsley RA. 2015. Signatures of adaptation in human invasive Salmonella Typhimurium ST313 populations from sub-Saharan Africa. PLoS Negl Trop Dis 9:e0003611. http://dx.doi.org/10.1371 liournal.pntd.0003611.

141. Wrande M, Andrews-Polymenis H, Twedt DJ, Steele-Mortimer O, Porwollik S, McClelland M, Knodler LA. 2016. Genetic determinants of Salmonella enterica serovar Typhimurium proliferation in the cytosol of 
epithelial cells. Infect Immun 84:3517-3526. http://dx.doi.org/10.1128 /IAI.00734-16.

142. Schlumberger MC, Hardt WD. 2006. Salmonella type III secretion effectors: pulling the host cell's strings. Curr Opin Microbiol 9:46-54. http://dx.doi.org/10.1016/j.mib.2005.12.006.
143. Rosselin M, Virlogeux-Payant I, Roy C, Bottreau E, Sizaret PY, Mijouin L, Germon P, Caron E, Velge P, Wiedemann A. 2010. Rck of Salmonella enterica, subspecies enterica serovar Enteritidis, mediates Zipper-like internalization. Cell Res 20:647-664. http://dx.doi.org /10.1038/cr.2010.45. 